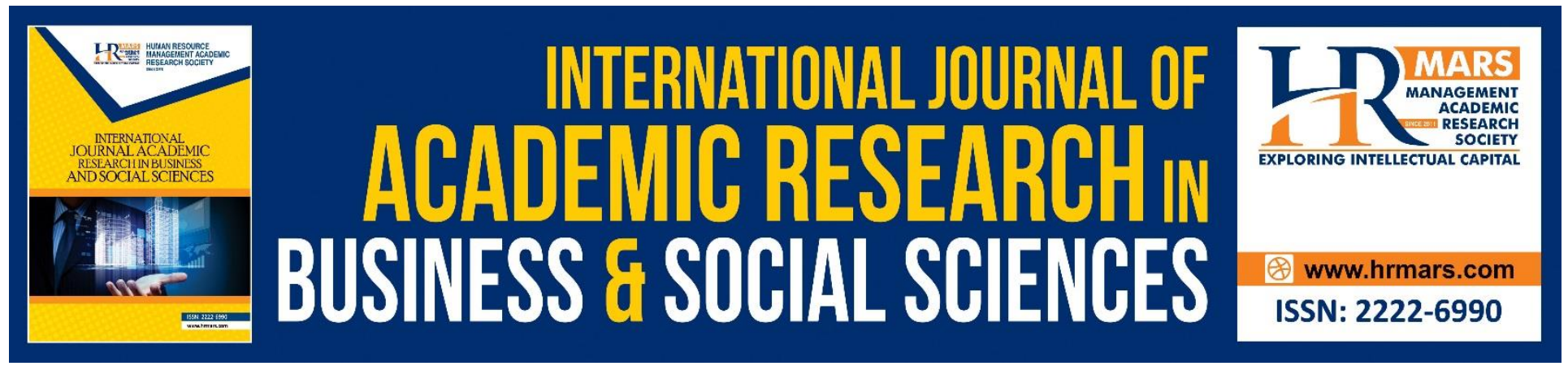

\title{
Influence of Perceived Stress and Organizational Justice on Employee Wellbeing amongst Academia: A Conceptual Paper
}

\author{
Obobanyi Momohjimoh Ahmed, Bidayatul Akmal Mustafa Kamil, and Awanis \\ Ku Ishak
}

To Link this Article: http://dx.doi.org/10.6007/IJARBSS/v8-i8/4477

DOI: $\quad 10.6007 /$ IJARBSS/v8-i8/4477

Received: 29 July 2018, Revised: 14 August 2018, Accepted: 28 August 2018

Published Online: 01 September 2018

In-Text Citation: (Ahmed, Kamil, \& Ishak, 2018)

To Cite this Article: Ahmed, O. M., Kamil, B. A. M., \& Ishak, A. K. (2018). Influence of Perceived Stress and Organizational Justice on Employee Wellbeing amongst Academia: A Conceptual Paper. International Journal of Academic Research in Business and Social Sciences, 8(8), 396-409.

\section{Copyright: (C) 2018 The Author(s)}

Published by Human Resource Management Academic Research Society (www.hrmars.com)

This article is published under the Creative Commons Attribution (CC BY 4.0) license. Anyone may reproduce, distribute, translate and create derivative works of this article (for both commercial and non-commercial purposes), subject to full attribution to the original publication and authors. The full terms of this license may be seen

at: http://creativecommons.org/licences/by/4.0/legalcode

Vol. 8, No. 8, August 2018, Pg. 396 - 409

http://hrmars.com/index.php/pages/detail/IJARBSS

JOURNAL HOMEPAGE

Full Terms \& Conditions of access and use can be found at http://hrmars.com/index.php/pages/detail/publication-ethics 


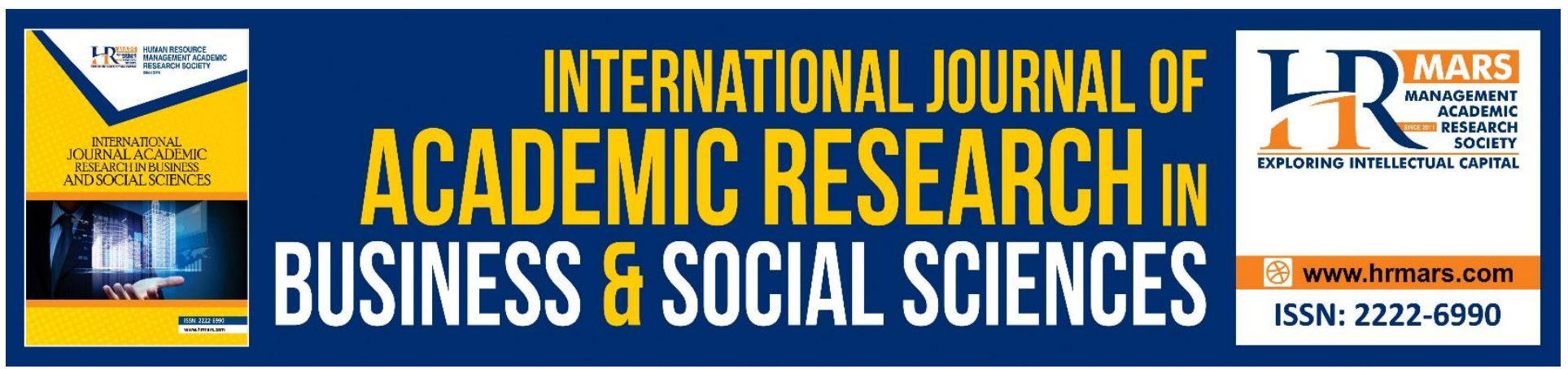

\title{
Influence of Perceived Stress and Organizational Justice on Employee Wellbeing amongst Academia: A Conceptual Paper
}

\author{
Obobanyi Momohjimoh Ahmed ${ }^{1,4}$, Bidayatul Akmal Mustafa Kamil², \\ and Awanis Ku Ishak ${ }^{3}$ \\ ${ }^{1}$ School of Business Management, Universiti Utara Malaysia, 06010, Sintok, Kedah, Malaysia. \\ E-mail: ahmedomj200@gmail.com \\ ${ }^{2}$ School of Business Management, Universiti Utara Malaysia, 06010, Sintok, Kedah, Malaysia. \\ E-mail: bidayatul@uum.edu.my \\ ${ }^{3}$ School of Business Management, Universiti Utara Malaysia, 06010, Sintok, Kedah, Malaysia. \\ E-mail: awanis@uum.edu.my \\ ${ }^{4}$ Department of Business Admin. \& Management, Waziri Umaru Federal Polytechnic, \\ Birnin Kebbi, Kebbi State, Nigeria.
}

\begin{abstract}
This paper proposes a conceptual model and states valid propositions to be tested by future researchers empirically. The model explicates the influence of perceived stress and organizational justice on employee wellbeing amongst academia. Being a conceptual paper, it reviewed scholarly articles on the variables of the study in accordance with theoretical perspectives. The paper draws inference from both job demands resources (JDR) theory and Adams equity theory to explain and support the conceptual model. This study would assist policy makers and university authorities in particular to comprehend the theoretical importance of sound wellbeing of academics in higher educational institutions (HEIs). The proposed model would have several significant implications for understanding, creating awareness and promoting employee wellbeing as well as contributes to existing works on wellbeing.
\end{abstract}

Keywords: Perceived Stress, Organizational Justice, Employee Wellbeing, Academia, JDR Model, Adams Equity Theory.

\section{Introduction}

Extant study has shown that poor wellbeing of employees in a workplace is detrimental to efficiency and effectiveness of organizations (Miller, 2016; Page \& Vella-Brodrick, 2009). Moreover, employee wellbeing explains the equilibrium level between the workers' resource pool and the challenges (demands) facing them, and whenever the challenges are greater than the resources at their disposal to mitigate against the pressures of demands, there will be issues with their wellbeing (Dodge, Daly, 
Huyton, \& Sanders, 2012). It is pertinent to note that employee wellbeing is associated with a number of important work outcomes like absenteeism, employees' turnover, quality defects, workplace accidents, job performance, profitability, and employee retention (Erdogan, Bauer, Truxillo, \& Mansfield, 2012).

Largely, the costs of poor wellbeing of workers to the productivity of organizations cannot be underestimated. For example, it was reported that the Conference Board of Canada estimated that Canadian economy lost a huge sum of US dollars (\$16.6 billion) in 2012 as a result of workplace absenteeism, which was related to negative outcome of employee wellbeing (Nguyen, 2013). Similarly, Black (2008) documented that the economic loss of working age ill-health in the UK was projected at well over 100 billion pound starling annually (Miller, 2016). Also, in United States, the estimated costs of between $\$ 30-\$ 44$ billion dollars was lost annually to depression, and additional 200 million workdays lost to absenteeism yearly (Dagenais-Desmarais \& Savoie, 2012). In Nigeria, poor wellbeing of employees at work has reached an alarming proportion as manifested in the recent increase in depression and suicide cases of workers in both public and private organizations (Muanya \& Ezea, 2017).

In particular, the academic members were subjected to such precarious conditions of non-payment or half-paid salaries, academic workloads, poor facilities and equipment, and incessant ASUU strikes among others that were generally perceived as the antecedents of poor wellbeing of faculty staff (Akinmayowa \& Kadiri, 2014; Umeh \& Matthew, 2017). Moreover in recent times, the society has raised serious concern over the quality of Nigerian universities graduates. For example, employers of labour often complains of poor competences demonstrated by graduates of these universities (Onuoha \& Ewuzie, 2012). Additionally it was reported that the former president of Nigeria (Goodluck Jonathan), lamented that the Nigerian graduates could not secure employment opportunities as a result of poor basic competences and skills demanded by the employers (Otokunefor, 2011). Also, Lawal (2013) opines that poor conditions of service in the university systems made lecturing job unattractive to quality and first class graduates to take up appointment with the universities. In view of all these, poor wellbeing of academics would impair the needed strengths to impart knowledge effectively to the students which eventually manifest as poor quality graduates from these universities.

Given the huge costs of poor wellbeing of employees at work, more studies are needed to understand the underlying problems of wellbeing in HEls. The paucity of researches on wellbeing in HEls in literature particularly motivated this present study to attempt to bridge the gap. Hence, 'the influence of perceived stress and organizational justice on employee wellbeing amongst academia' with emphasis on Nigeria HEls is arguably a rewarding exercise and timely too. In order to accomplish the objective of this study, the remaining sections are organised as follows. The next section review the relevant literature related to wellbeing, perceived stress, and organizational justice leading to proposition statements, and final section discusses the conclusion.

\section{Literature Review}

Employee wellbeing

Employee wellbeing at work apparently reflects the prevalence of positive emotions and moods of individuals on their job, and in particular the feelings that the work provides the opportunities to develop their potentials into self-actualization (Dodge et al., 2012; Ryff, 2014). Employee wellbeing is inclusive of both affective aspects and cognitive domains (Santos, Goncalves, \& Gomes, 2013). Moreover, employee wellbeing at work is viewed as a condition perceived to be more than just an 
INTERNATIONAL JOURNAL OF ACADEMIC RESEARCH IN BUSINESS AND SOCIAL SCIENCES

Vol. 8, No. 8, August 2018, E-ISSN: 2222-6990 @ 2018 HRMARS

avoidance of physically ill, but broadly reflective of bio-psycho-social perspectives that includes physical, mental and social health of workers (Tehrani, Humpage, \& Willmott, 2007). Employee wellbeing is associated with several important work implications like workplace accidents, employee turnover, quality defects, absenteeism, performance, and profitability, among others in organizations (Erdogan et al., 2012).

In particular, organizations need workers to perform at their best in a sustainable manner. Moreover, there are associates cost of poor wellbeing to employee performance vis-à-vis obvious benefits of supporting and promoting wellbeing for workers' performance (Miller, 2016). The levels of people's performance in the organizations determine the degree of their effectiveness. People are the central domains of productivity debate. Hence, their wellbeing should be given attention in order to fulfil this important function. Furthermore, evidences are abound that people are the central areas of productivity aspirations in organizations. For instance, the UK chancellor's budget speech of 2016 unequivocally emphasized that 'a nation's productivity is no more and no less than the combined talents and efforts of the people in the systems' (Miller, 2016). This emphasizes the significant of workers in organizations.

Unfortunately, when employees were inflicted with high levels of stress, disengaged, high turnover and high degrees of sickness absenteeism may not deliver on performance objectives of the organization (Chartered Institute of Personnel and Development, 2014). This study therefore postulates that any organization that promotes employee wellbeing as its core human resource strategy will benefits tremendously from productivity debate which is largely a function of employee positive wellbeing status.

In addition, wellbeing has been divided into two approaches in the literature, namely subjective wellbeing (SWB) centred on hedonic perspective, and psychological wellbeing (PWB) focused on eudaimonic perspective (Kim, Fouad, Maeda, Xie, \& Nazan, 2017; Ryan \& Deci, 2001). Wellbeing is described as a person's cognitive and affective evaluation of self, especially with higher wellbeing experience of life satisfaction, optimal positive affect, and minimal negative affect from hedonic perspective (Duffy, Blustein, Diemer, \& Autin, 2016). Whereas, significant emphasis is placed on individuals' indicatives of developing their lives' self-actualization potentials as basic focus of eudaimonic wellbeing (Blustein, 2008; Ryff, 1989, 2014).

However, it has been argued that subjective wellbeing (SWB) focuses substantially on temporary situations that are not sustaining overtime (Baumeister, Vohs, Aaker, \& Garbinsky, 2013), and that psychological wellbeing (PWB) is more beneficial in psychological functioning and other wellbeing indicators (Steger, Kashdan, \& Oishi, 2008). Nevertheless, extant studies have suggested that there is need for the inclusion of both SWB and PWB in the study of wellbeing in order to optimally capture the impacts of wellbeing in the work environment (Hernandez, Bassett, Boughton, Schuette, Shiu, \& Moskowitz, 2017; Robertson \& Cooper, 2010). Wellbeing largely constitutes some degrees of workers' positive emotions as well as purpose and meaning in their work.

This study operationalizes psychological wellbeing (PWB) as a multidimensional construct that reflects a wide-range of wellbeing which includes positive evaluations of individual's life, a sense of growth, a belief that life is meaningful, a healthy relationships with colleagues at work, ability to effectively conduct one's life, and a feeling of self-actualisation. Whereas, life satisfaction is conceptualised as the individuals' evaluative assessment of their lives and the cognitive appraisal of satisfaction with their life circumstances as a whole. 
INTERNATIONAL JOURNAL OF ACADEMIC RESEARCH IN BUSINESS AND SOCIAL SCIENCES

Vol. 8, No. 8, August 2018, E-ISSN: 2222-6990 @ 2018 HRMARS

\section{Theoretical Perspectives}

The job demands resources (JDR) theory

Generally, jobs are primarily constituted of two characteristics that either impair or promote employee wellbeing in organizations. The JDR theory proposes two key underlying psychological processes such as health impairment process and motivational-enhancing system (Bakker \& Demerouti, 2016; Demerouti, Bakker, Nachreiner, \& Schaufeli, 2001). The health impairment system believes that job demands diminish workers' physical and psychological resources, and in effect lead to a state of fatigue and tiredness of individuals at work. Thus, the continual depletion of workers' strengths will ultimately translate to their health problems and poor wellbeing (Hu, Schaufeli, \& Taris, 2011; Van den Tooren \& de Jong, 2014). On the other hand, motivational-enhancing process espouses that job resources are intrinsically or extrinsically beneficial, and as such display an energizing function to employees at work. As a result of these motivational attributes, job resources can have a rewarding impacts on workers' health and wellbeing (Hu et al., 2011). Additionally, the JDR theory proposes that job resources buffer the negative impacts of job demands on workers' health and wellbeing (Bakker \& Demerouti, 2016), particularly if the workers have sufficient job resources to counter their job demands, the negative impacts of job demands on employees' health and wellbeing can be effectively neutralised. Hence, the JDR theory seems more relevant and appropriate to apply to the theoretical framework of this study.

Adams equity theory

Equity theory is about fairness in the distribution of resources between employees and employer in organizations. It is determined by comparing the ratio of employee contributions (costs/inputs) and benefits (rewards/outcomes) accrue to him/her. It is regarded as one of the justice theories which was developed in the 1960s (Adams, 1963). Adams (1963) proffers that workers usually advocate to maintain fairness between the inputs they brought to the work and the benefits they get from the job as compared with inputs and benefits of other colleagues. It is believed that employees value fairness in their treatment which gives them motivation or strengths to do their work effectively. This theory postulates that workers who experience being under-rewarded or over-rewarded will suffer from distress. Underpayment inequity usually induced anger, whereas overpayment equity induced guilt (Spector, 2008). Employees usually seek to maximize their outcomes, but whenever they find themselves participating in an inequitable relationship, they become distressed. Furthermore, Sethi, Iqbal, and Rauf (2013) suggest that individuals are interested in fairness of situations in their daily lives and across several contexts, especially as it concerns distributive, procedural, and interactional justice in organizations.

\section{Perceived Stress and Employee Wellbeing}

Stress is viewed as a health risk for a number of psychological, behavioural, and medical disorders (Quick \& Henderson, 2016). Work-related stress does not only negatively affect employees' productivity and creativity, but also their morale, health, and wellbeing (Bakker \& Demerouti, 2016; Karasek, 1979). Perceived stress is been described as harmful physical and emotional reactions that occurs when the demands of the job are not compatible with the resources, abilities, and needs of the employee (Marzabadi \& Tarkhorani, 2007). It is defined as a condition arising from the interaction of individuals with their jobs which is characterized by the dynamics within the employees that compel them to deviate from their normal functioning or flourishing (Adegoke, 2014).

In addition, stress seems to be detrimental to an individual's emotional stability and behaviour, as well as affects the long-term psychological wellbeing of the workers (Akinmayowa, 2009). Perceived 
INTERNATIONAL JOURNAL OF ACADEMIC RESEARCH IN BUSINESS AND SOCIAL SCIENCES

Vol. 8, No. 8, August 2018, E-ISSN: 2222-6990 @ 2018 HRMARS

stress can be seen as a consequence of mismatch between job demands and job resources (Jain, Giga, \& Cooper, 2013; Bakker \& Demerouti, 2016). Hence, working under persistent stress for a long period of time may render the employee exhausted and less productive on the job, especially the faculty staff. Moreover, the antecedent factors adjudged to contribute to stress among faculty members include performance pressure, academic workloads, role ambiguity, student-related issues, workfamily interface, and role conflicts (Ahsan, Abdullah, Fie, \& Alam, 2009; Akbar \& Akhter, 2011). Therefore, stress can potentially cause fatigue, nervous tension and anxiety to academic members (Showkat \& Jahan, 2013).

Furthermore, this study operationalizes perceived stress as a process of adjusting to cope with jobrelated responses that threaten to render employee ineffective to function physically and psychologically in the work environment. In particular, a combination of perceived stress, work demands, and environmental stressors are capable of stimulating stress reactions. For instance, work-to-family conflict is one of many remarkable factors that can trigger stressful environment for faculty members (Hammer, Kossek, Anger, Bodner, \& Zimmerman, 2011). In addition, stressors are capable of adversely impair operational effectiveness and efficiency, reduce workers' motivation and satisfaction, increase employee turnover intention, ill health, and the overall functioning of organizations (Ongori \& Agolla, 2008).

Moreover, in a study conducted on several causes of stress among UK academics, almost $75 \%$ of the participants showed that they were suffering from work-related stressors, while $45 \%$ showed familyrelated stressors (Abouserie, 1996). Professors in the UK attribute their stressors from time pressures, research activities, and interpersonal associations with colleagues (Abouserie, 1996). Additionally, there is a shift from collegiate culture of cooperation and shared values towards an approach of bureaucratic and non-participative style of authorities in the university settings (Tapper, 1995). Besides, it seems that teaching is one of the most stressful occupations that is related to wellbeing challenges, and that stressor is capable of inflicting damaging effect on mental and physical health of individuals (Thabo, 2010; Thoits, 2010).

Theoretically, with inference to health impairment process of the JDR theory, which states that job demands erode workers' physical and psychological resources thereby leading to a state of fatigue and tiredness (Bakker \& Demerouti, 2016; Demerouti et al., 2001). As a consequence to the continual erosion of workers' strengths, it will eventually culminate into their health problems and poor wellbeing (Hu, Schaufeli, \& Taris, 2011). For instance, in a situation where academics were given a lot of responsibilities with excess workloads, time pressures, large classes of students to teach, conducting other researches for publications, etc., but were being paid incomplete salaries at the end of month that cannot meet their financial obligations. This kinds of experiences would naturally increase stress at work thereby impacting negatively on their health, wellbeing, and performance on the job (van den Tooren \& de Jong, 2014).

Additionally, life satisfaction is described as an individual's evaluative appraisal of his/her life in accordance with self-set criteria (Diener, 1984; Erdogan et al., 2012). Life satisfaction is an evaluative appraisal dimension of a person's subjective wellbeing (SWB). Hence, SWB comprises of three components such as life satisfaction, positive affect, and negative affect (Diener, 1984). However, life satisfaction constitutes the evaluative and judgmental dimension of SWB, while emotional components are the positive and negative affects (Hamama, Shachar, \& Rosenbaum, 2013). It was suggested that workers who were emotionally drained at work suffer from poor life satisfaction because they were left with insufficient personal resources (strengths) to use for family activities that contributes significantly to satisfaction with life of employees (Boekhorst, Singh, \& Burke, 2015). 
More so, a research conducted on work intensity (job demands), emotional exhaustion and life satisfaction, and data were obtained from 149 hospital nurses. The data were analysed adopting hierarchical regression and bootstrapping techniques (Boekhorst et al., 2015). It was found that work intensity or high job demands were negatively related to life satisfaction of the workers. On the bases of these theoretical perspectives and prior empirical findings, the study proposes that:

Proposition 1: There will be a negative relationship between perceived stress and psychological wellbeing amongst academia.

Proposition 2: There will be a negative relationship between perceived stress and life satisfaction amongst academia.

\section{Organizational Justice and Employee Wellbeing}

Organizational justice is the degree at which some activities of the organization is perceived as being fair or equitable with inference to some established standards in the organization (Cropanzano, Rupp, Mohler, \& Schminke, 2001). It was often debated that justice perceptions are the prerequisites for the cushioning of job control in relationship to job demands in a work setting (Proost, Verboon, \& van Ruysseveldt, 2015). Therefore, perception of justice in a work environment is a significant antecedent for the regulating function of job control on the impact of job demands on turnover intentions and contentment of the workers (Proost et al., 2015). In addition, organizational justice is the workers' anticipated equitable handling by an employer, and employees' behavioural responses to the equity (James, 1993). Study on organizational justice always focuses on workplace justice and employees' anticipation of justice in all organization activities (Suliman, 2013).

Furthermore, the association between organizational justice and employee wellbeing seems to cut across several occupations such as in health, psychology, education, occupational health and safety, and business among others (Fujishiro \& Heaney, 2009). Connie and Fujimoto (2016) described employee wellbeing as the overall welfare or quality of life of workers that include their physical and mental health conditions. Moreover, negative perception of organizational justice can translate to poor workers' health (Fujishiro \& Heaney, 2009). Despite the apparent theoretical importance of this association between organizational justice and employee wellbeing, only few works have explored the relationship (Connie \& Fujimoto, 2016), and such neglect is critical because issues related to worker's wellbeing have direct and indirect impacts on employee performance and wellbeing (Shani \& Pizam, 2009). In addition, work-related stress is a potential causes of employee health and wellbeing challenges. For instance, prolong exposure to stressful conditions like heavy workloads, lack of inputs in decision making process, high demands and low resources, perceived unfairness, and lack of supervisor support can negatively affect employees' level of stress and wellbeing in organization (Bakker \& Demerouti, 2016; Qin, DiRenzo, Xu, \& Duan, 2014).

Additionally, this study conceptualizes organizational justice (OJ) as the workers' perceptions of fair treatment from organization's management and employees' behavioural reactions to such actions in return. The assessment of justice in organization by workers focuses on three perspectives such as first, distributive justice which examines how fair in the allocation of resources in relations to the contribution of workers to the organization (Adams, 1965); second, procedural justice is the level at which decision-making processes are perceived to be equitable (Thibaut \& Walker, 1975); and third, interactional justice which focuses on the treatment received from management in terms of respect, dignity and timely dissemination of information from authorities (Bies \& Moag, 1986). Also, OJ can accelerate performance in the assigned responsibilities and the contextual performance in organization (Devonish \& Greenidge, 2010). It reduces counter-productive behaviours and inspires 
INTERNATIONAL JOURNAL OF ACADEMIC RESEARCH IN BUSINESS AND SOCIAL SCIENCES Vol. 8, No. 8, August 2018, E-ISSN: 2222-6990 @ 2018 HRMARS

the norms of reciprocity in work environment. OJ is found to be positively associated with employee wellbeing at work, enhances the psychological wellbeing of workers and minimizes negative stress (Cropanzano, Goldman, \& Benson, 2005). In contrast, there are several negative features of organizational injustice such as: first, injustice encourages counter-productive behaviours and reduces organizational effectiveness (Devonish \& Greenidge, 2010); second, injustice impairs employees' contributions to be adequately evaluated and rewarded; third, the perception of injustice indicates that the workers are not valued properly; and fourth, injustice shows a violation of important social norms in the organization system (Cropanzano et al., 2001). Generally, dealing equitable or fairly with workers would not only improve their wellbeing and sound health, but also inspire clients' satisfaction and commitment.

Furthermore, it is argued that high level perceptions of justice in organizations can lead to high performance, fewer counterproductive behaviour, high organizational commitment, high involvement and engagement, high job satisfaction, and more of organizational citizenship behaviour (Tlaiss et al., 2015). For example, in a research conducted by Moorman (1991) with 225 respondents in two organizations in the US revealed that workers who experienced fair treatment change to embrace desirable attitudes towards their responsibilities and superiors. In another study by Findler et al. (2007) with 250 Israeli workers, reported that worker who experienced fairness in organizational practices, acknowledged a significant wellbeing improvement. Additionally, in Yom's (2010) research with 274 nurses in government hospital in Korea, found that the three justice dimensions of distributive, procedural, and interactional were influential in reducing turnover rates of nurses from their organizations. Similarly, Neuman and Baron (2005) undertook a research with 452 respondents from public and private organizations in the US and found that the greater the workers' perceptions of unfairness, the higher their intent to display insubordination to supervisors as well as involving in several forms of undesirable behaviours. Also in a related study by Lim and Cortina (2005) found that interpersonal maltreatment in organization impacted negatively on workers' wellbeing as a result of unfair performance evaluation which denied them promotions because of strained relationship with their employers. As a consequence to this perceived unfair treatment, the workers developed negative outcomes like psychological distress, low job satisfaction and reduced job performance (Lim \& Cortina, 2005).

Theoretically, in line with the assumption of Adams equity theory (Adams, 1963) which postulates that workers of organizations seek to preserve fairness between the inputs they brought to the work and the benefits also earn from the work against anticipated inputs and benefits of related colleagues. This theory added that workers who experience being under-rewarded or over-rewarded will suffer from distress. The tenet of this theory aligns with faculty staff conditions who performed their job responsibilities and yet being denied of complete salaries at the end of the month. There is an apparent inequity in this situation. This would undoubtedly incapacitated the academic staff from meeting their financial obligations which most often translates to health issues of the academics such as headache, high blood pressures, stress and depression among others (Adeoti, Mohd-Shamsudin \& Chong, 2017), poor wellbeing and performance (van den Tooren \& de Jong, 2014).

In addition, life satisfaction could be explicated as a person's cognitive assessment of his/her life conditions as a whole in accordance with self-set standards (Diener, 1984). Life satisfaction comprises of cognitive and judgmental components of individual's subjective wellbeing (SWB). For instance, the quality of relationships enjoy among employees in organizations is a potent predictor of life satisfaction (Erdogan et al., 2012). Furthermore, it is argued that a healthy psychosocial climate in organizations can positively impact on employee wellbeing (Ernst Kossek, Kalliath, \& Kalliath, 2012). 
Life satisfaction is operationalizes in this study as the individual's evaluative and judgmental appraisal of his/her entire working life conditions with a view of reflecting greater wellbeing.

Moreover, extant study suggests that workers who are satisfied with life are more likely to be pleasant to work with, more helpful, and less stressful at work (Lambert, Hogan, Jiang, Elechi, Benjamin, \& Dupuy, 2010). Apparently, employees' perception of justice in the organization's activities can provide them with positive feelings (Lambert \& Hogan, 2012), and workers' positive perception of organizational justice can offer greater impacts on their satisfaction with overall lives (Lambert \& Hogan, 2012). Despite the limited research conducted to investigate the association between life satisfaction and work-related outcomes like job performance, turnover intention, organizational commitment, the results revealed that life satisfaction impacts positively on workrelated outcomes (Erdogan et al., 2012). In line with Adams equity theory (1963) in supporting the association between organizational justice and life satisfaction, the theory proposes that the major input into job performance and satisfaction is the perception of individual's input to outcomes ratio as compared to others' input to outcomes ratio in the workplace, where the comparison is perceived equal, there will be perceived fairness or equity. This implies that whenever there is perceived fairness in an organization, the workers' life satisfaction will be positively enhanced (Lambert \& Hogan, 2012). On the bases of these theoretical perspectives and earlier empirical findings, the study proposes that:

Proposition 3: There will be a positive relationship between organizational justice and psychological wellbeing amongst academia.

Proposition 4: There will be a positive relationship between organizational justice and life satisfaction amongst academia.

\section{Research Framework}

Based on the postulations of both the JDR theory and Adams equity theory as well as earlier discussion on employee wellbeing, this study proposes a conceptual model. In particular, job demands and resources (JDR) theory explains the negative relationship between perceived stress on both psychological wellbeing and life satisfaction. On the other hand, Adams equity theory explains the positive relationship between organizational justice on both psychological wellbeing and life satisfaction. Figure 1 shows the conceptual model.

IV

DV

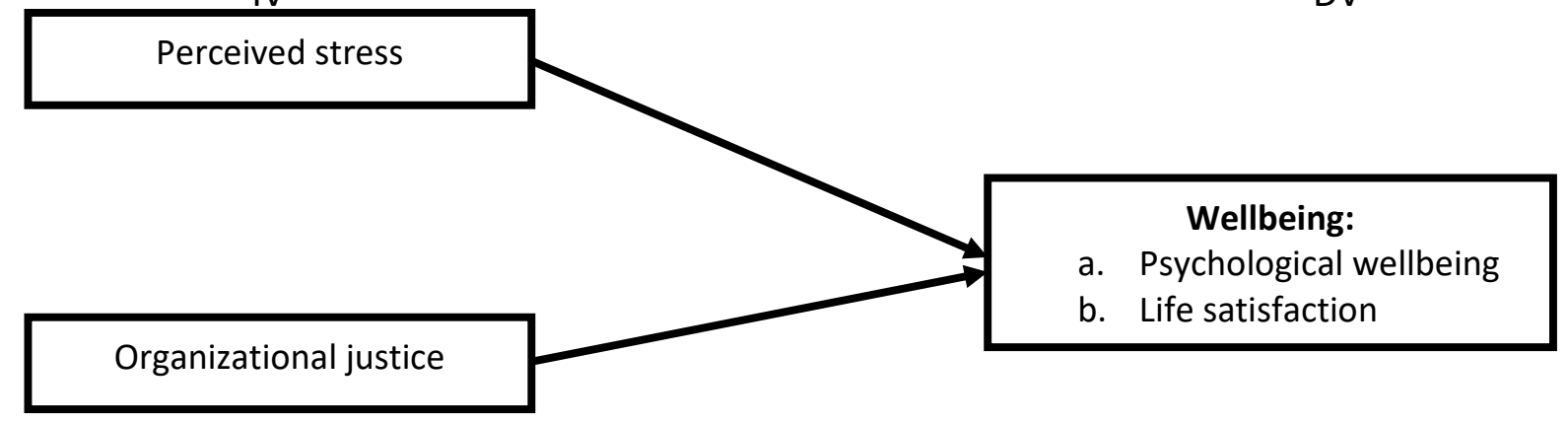

Figure 1: Conceptual Model.

\section{Conclusion}

This paper has established a model on the influence of perceived stress and organizational justice on employee wellbeing amongst academia as shown in figure 1. Therefore, in agreement with prior studies, this paper is summings-up that wellbeing at work and better performance should be given 
INTERNATIONAL JOURNAL OF ACADEMIC RESEARCH IN BUSINESS AND SOCIAL SCIENCES

Vol. 8, No. 8, August 2018, E-ISSN: 2222-6990 @ 2018 HRMARS

priority attention by the authorities of organizations, especially universities. For instance, the enormous costs of poor wellbeing on workers can substantially drained the financial resources of organizations through absenteeism, low productivity, turnover of workers and sick leaves. Perhaps the use of more job resources can potentially buffer the negative effects of high job demands encountered by academics to reduce their stressors and improve wellbeing. In the same vein, a proper dispensation of organizational justice by the management of universities where nobody perceived unfair treatment in terms of input-outcomes ratio comparisons, will go a long way to boost sound health and positive wellbeing of academics.

This article proposes a framework supported by both job demands resources (JDR) theory and Adams' equity theory with the aim of creating an understanding of the theoretical importance of wellbeing of academia in HEls, especially in Nigeria. Expectedly, based on the assumptions provided, empirical study of this model will make theoretical contributions to the domain of job demands resources theory (Bakker \& Demerouti, 2016; Demerouti et al., 2001) by ways of the university authorities taken steps to enrich the job resources of lecturers over and above their job demands which can potentially enhance their health conditions, wellbeing, and performance. Also, in the realm of practical contributions, the university authorities can make tremendous use of organizational justice, especially the mechanism of overall justice which include distributive, procedural, and interactional justices to improve the wellbeing of faculty staff of HEls (Cropanzano et al., 2005).

\section{References}

Abouserie, R. (1996). Stress, coping strategies and job satisfaction in university academic staff. Educational psychology, 16(1), 49-56.

Adams, J. S. (1963). Towards an understanding of inequity. Journal of Abnormal and Social Psychology, 67, 422-436.

Adams, J. S. (1965). Inequity in social exchange. Advances in experimental social psychology, 2, 267299.

Adegoke, T. G. (2014). Effects of occupational stress on psychological wellbeing of police employees in Ibadan metropolis, Nigeria. African Research Review, 8(1), 302-320.

Adeoti1, M.O., Mohd.Shamsudin, F. \& Yen Wan, C. (2017). Effects of occupational stress and workplace spirituality on workplace deviance in academia, Asian Journal of Multidisciplinary Studies, 5(9), 99-106.

Ahsan. N., Abdullah. Z., Fie. D.Y.G., \& Alam, S.S. (2009). A study of job stress on job satisfaction among university. European Journal of Social Sciences, 8(1), 121-131.

Akbar, A., \& Akhter, W. (2011). Faculty stress at higher education: A study on the business schools of Pakistan. World Academy of Science, 73, 1089-1093.

Akinmayowa, J.T. \& Kadiri, P.A. (2014). Stress among Academic Staff in a Nigerian University. Covenant Journal of Business and Social Sciences (CJBSS) 65(1), 73-91.

Bakker, A.B. \& Demerouti, E. (2017). Job Demands-Resources Theory: Taking Stock and Looking Forward. Journal of Occupational Health Psychology, 22(3), 273-285.

Baumeister, R. F., Vohs, K. D., Aaker, J. L., \& Garbinsky, E. N. (2013). Some key differences between a happy life and a meaningful life. The Journal of Positive Psychology, 8(6), 505-516.

Bies, R. J., \& Moag, J. S. (1986). Interactional justice: Communication criteria of fairness. Research on negotiation in organizations, 1(1), 43-55.

Black, C. (2008), "Working for a healthier tomorrow: Dame Carol Black's review of the health of Britain's working age population presented to the secretary of state for work and pensions", 
INTERNATIONAL JOURNAL OF ACADEMIC RESEARCH IN BUSINESS AND SOCIAL SCIENCES

Vol. 8, No. 8, August 2018, E-ISSN: 2222-6990 @ 2018 HRMARS

Stationery Office, London, available at: www.gov.uk/government/uploads/system/uploads/attachment_data/file/209782/hwwbworking-for-a-healthier-tomorrow.pdf (accessed 26 June 2016).

Blustein, D. L. (2008). The role of work in psychological health and well-being: A conceptual, historical, and public policy perspective. American Psychologist, 63, 228-240. doi:10.1037/0003066X.63.4.228

Boekhorst, J.A., Singh, P. \& Burke, R. (2015). "Work intensity, emotional exhaustion and life satisfaction: the moderating role of psychological detachment", Personnel Review, https://doi.org/10.1108/PR-05-2015-0130

Chartered Institute of Personnel and Development (2014), "Megatrends: are we working harder than ever?" research report, CIPD, London.

Connie, H.L. \& Fujimoto, Z.Y. (2016). Inclusion, organisational justice and employee wellbeing. International Journal of Manpower, 37(6), 1-24.

Cropanzano, R., Goldman, B. \& Benson, L. (2005). Organizational justice. In J. Barling, K. Kelloway \& M. Frone (Eds), Handbook of work stress. Beverly Hils, CA: Sage.

Cropanzano, R., Rupp, D.E., Mohler, C.J. \& Schminke, M. (2001). Three roads to organizational justice. Research in Personnel and Human Resources Management, 20, 1-113.

Dagenais-Desmarais, V. \& Savoie, A. (2012). What is Psychological Well-Being, Really? A Grassroots Approach from the Organizational Sciences. Journal of Happiness Studies. DOI: 10.1007/s10902-011-9285-3

Demerouti, E., Bakker, A. B., Nachreiner, F., \& Schaufeli, W. B. (2001). The job demands-resources model of burnout. Journal of Applied psychology, 86(3), 499.

Devonish, D. \& Greenidge, D. (2010). The effect of organizational justice on contextual performance, counterproductive work behaviours, and task performance: Investigating the moderating role of ability-based emotional intelligence. International Journal of Selection and Assessment, 18, 75-86.

Diener, E. (1984). Subjective well-being. Psychological Bulletin, 95, 542-575.

Dodge, R., Daly, A. P., Huyton, J., \& Sanders, L. D. (2012). The challenge of defining wellbeing. International Journal of Wellbeing, 2(3).

Duffy, R. D., Blustein, D. L., Diemer, M. A., \& Autin, K. L. (2016). The psychology of working theory. Journal of Counseling Psychology, 63, 127. Doi.10.1037/cou0000140

Erdogan, B., Bauer, T.N., Truxillo, D.M. \& Mansfield, L.R. (2012), "Whistle while you work a review of the life satisfaction literature", Journal of Management, 38(4), 1038-1083.

Ernst Kossek, E., Kalliath, T. \& Kalliath, P. (2012), “Achieving employee wellbeing in a changing work environment: An expert commentary on current scholarship", International Journal of Manpower, 33(7), 738-753.

Findler, L., Wind, L. H., \& Barak, M. E. M. (2007). The challenge of workforce management in a global society: Modelling the relationship between diversity, inclusion, organizational culture, and employee wellbeing, job satisfaction and organizational commitment. Administration in Social Work, 31(3), 63-94.

Fujishiro, K. \& Heaney, C.A. (2009), "Justice at work, job stress, and employee health", Health Education \& Behavior, 36(3), 487-504.

Hamama, L., Ronen, T., Shachar, K. \& Rosenbaum, M. (2013), "Links between stress, positive and negative affect, and life satisfaction among teachers in special education schools", Journal of Happiness Studies, 14(3), 731-751. 
INTERNATIONAL JOURNAL OF ACADEMIC RESEARCH IN BUSINESS AND SOCIAL SCIENCES

Vol. 8, No. 8, August 2018, E-ISSN: 2222-6990 @ 2018 HRMARS

Hammer, L. B., Kossek, E. E., Anger, W. K., Bodner, T., \& Zimmerman, K. L. (2011). Clarifying workfamily intervention processes: The roles of work-family conflict and family-supportive supervisor behaviors. Journal of Applied Psychology, 96(1), 134.

Hernandez, R., Bassett, S.M., Boughton, S.W., Schuette, S.A., Shiu, E.W. \& Moskowitz, J.T. (2017). Psychological Well-Being and Physical Health: Associations, Mechanisms, and Future Directions. Emotion Review, 1-12. https://doi.org/10.1177/175407391769.

Hu, Q., Schaufeli, W.B., \& Taris, T.W. (2011). The Job Demands-Resources model: An analysis of additive and joint effects of demands and resources. Journal of Vocational Behaviour 79 181190.

Jain, A.K.; Giga, S.I. \& Cooper, C.L. (2013). Stress, Health and Well-Being: The Mediating Role of Employee and Organizational Commitment. International Journal of Environmental Research and Public Health, 10, 4907-4924.

James, K. (1993). The social context of organizational justice: Cultural, intergroup, and structural effects on justice behaviors and perceptions. Justice in the workplace: Approaching fairness in human resource management, 21-50.

Karasek, R.A. (1979). Job demands, job decision latitude, and mental strain: implications for job Redesign. Administrative Science Quarterly, 24(2), 285-308.

Kim, S. Y., Fouad, N., Maeda, H., Xie, H. \& Nazan, N. (2017). Midlife Work and Psychological WellBeing: A Test of the Psychology of Working Theory. Journal of Career Assessment 1-12.

Lambert, E.G. \& Hogan, N.L. (2012). Association between Distributive and Procedural Justice and Life Satisfaction among Correctional Staff: Research Note, Professional Issues in Criminal Justice 6(3 \& 4), 31.

Lambert, E. G., Hogan, N. L., Jiang, S., Elechi, O. O., Benjamin, B., Morris, A., \& Dupuy, P. (2010). The relationship among distributive and procedural justice and correctional life satisfaction, burnout, and turnover intent: An exploratory study. Journal of Criminal justice, 38(1), 7-16.

Lawal, Y.O. (2013). Education as an Instrument for Effective National Development: Which Way Nigeria. Business \& Entrepreneurship Journal, 2(2), 27-38.

Lim, S., \& Cortina, L. M. (2005). Interpersonal mistreatment in the workplace: the interface and impact of general incivility and sexual harassment. Journal of applied psychology, 90(3), 483.

Marzabadi, E.A. \& Tarkhorani, H. (2007). Job Stress, Job Satisfaction and Mental Health. Journal of Clinical and Diagnostic Research, 1(4), 224-234.

Miller, J. (2016),"The well-being and productivity link: a significant opportunity for research-intopractice", Journal of Organizational Effectiveness: People and Performance, 3(3), 289 - 311.

Moorman, R. H. (1991). Relationship between organizational justice and organizational citizenship behaviors: Do fairness perceptions influence employee citizenship? Journal of applied psychology, 76(6), 845.

Muanya, C. \& Ezea, S. (2017). Worrisome rising cases of suicides in Nigeria. The Guardian Saturday Magazine,

Neuman, J. H., \& Baron, R. A. (2005). Aggression in the workplace: A social-psychological perspective. Counterproductive work behavior: Investigations of actors and targets, 7, 13-40.

Nguyen, L. (2013). Canadian economy loses \$16.6 Billion annually due to absenteeism: Conference

Board, The Star. Retrieved from

http://www.thestar.com/business/economy/2013/09/23/absenteeism_cost_canad

a_lost_166_billion_study.html 
INTERNATIONAL JOURNAL OF ACADEMIC RESEARCH IN BUSINESS AND SOCIAL SCIENCES

Vol. 8, No. 8, August 2018, E-ISSN: 2222-6990 @ 2018 HRMARS

Ongori, H. \& Agolla, J.E. (2008). Occupational stress in organizations and its effects on organizational performance. Journal of Management and Resources, 8, 123-135.

Onuocha, I. \& Ewuzie, K. (2012) “Employers Worry as Nigerian Degrees Face Quality Test”, in Business Day, September 14th.

Otokunefor, T. (2011) "Why Nigerian Universities Produce Poor Quality Graduates", in Alpha Education Foundation, Educational Monograph Series, No. 3, March 25.

Page, K. M. \& Vella-Brodrick, D. A. (2009). The 'what', 'why' and 'how' of employee wellbeing: A new model. Social Indicators Research, 90, 441-458. Doi: 10.1007/s11205-008-9270-3

Proost, K., Verboon, P. \& van Ruysseveldt, J. (2015). Organizational justice as buffer against stressful job demands. Journal of Managerial Psychology, 30(4), 487-499.

Qin, X., DiRenzo, M.S., Xu, M. \& Duan, Y. (2014). When do emotionally exhausted employees speak up? Exploring the potential curvilinear relationship between emotional exhaustion and voice. Journal of Organizational Behaviour, 35(7), 1018-1041.

Quick, J.C. \& Henderson, D.F. (2016). Occupational Stress: Preventing Suffering, Enhancing Wellbeing; International Journal of Environmental Research and Public Health 13, 459;

Robertson, I.T. \& Cooper, C.I. (2010). Full engagement: the integration of employee engagement and psychological wellbeing. Leadership and Organization Development Journal, 31(4), 324-336.

Ryff, C. D. (1989). Happiness is everything, or is it? Explorations on the meaning of psychological wellbeing. Journal of personality and social psychology, 57(6), 1069.

Santos, J., Gonçalves, G. \& Gomes, A. (2013). Organizational culture and subjective and work wellbeing. The case of employees of portuguese universities. Journal of Spatial and Organizational Dynamics, I(3).

Sethi, M., Iqbal, H., \& Rauf, M. O. (2013). Relationship between Perceived Organizational Justice and the Employees Job Satisfaction. Abasyn Journal of Social Sciences, 7(1).

Shani, A. \& Pizam, A. (2009), "Work-related depression among hotel employees", Cornell Hospitality Quarterly, 50(4), 446-459.

Showkat, S., \& Jahan, N. F. (2013). Stress management practices in selected IT companies in Bangalore. Asia Pacific Journal of Management \& Entrepreneurship Research, 2(3), 106-116.

Spector, P.E. (2008). Industrial and Organizational Behavior (5th Ed.). Wiley: Hoboken, NJ.

Steger, M. F., Kashdan, T. B., \& Oishi, S. (2008). Being good by doing good: Daily eudaimonic activity and well-being. Journal of Research in Personality, 42(1), 22-42.

Suliman, A. (2013). Organizational justice and innovation in the workplace: The case of the UAE. Journal of Management Development, 32(9), 945-959.

Tapper, T. (1998). Continuity and change in the collegial tradition. Higher Education Quarterly. 52. 142-161.

Tehrani, N., Humpage, S. \& Willmott, B. (2007), “What's happening with well-being at work?” Change agenda, CIPD, London, available at: www.cipd.co.uk/NR/rdonlyres/DCCE94D7- 781A- 485AA702 6DAAB5EA7B27/0/whthapwbwrk.pdf (accessed 31 August 2016).

Thabo, F. (2010). Occupational stress among university employees in Botswana. European Journal of Social Sciences. 15(3), 313.

Thibault, J. W., \& Walker, L. (1975) Procedural justice: A psychological analysis. Hillsdale: Erlbaum.

Thoits, P. (2010). Stress and Health: Major findings and policy implications. Journal of Health and Social Behaviour. 51, 41-53. 
INTERNATIONAL JOURNAL OF ACADEMIC RESEARCH IN BUSINESS AND SOCIAL SCIENCES

Vol. 8, No. 8, August 2018, E-ISSN: 2222-6990 @ 2018 HRMARS

Tlaiss, H. A., \& Elamin, A. M. (2015). Exploring organizational trust and organizational justice among junior and middle managers in Saudi Arabia: trust in immediate supervisor as a mediator. Journal of Management Development, 34(9), 1042-1060.

Umeh, k. \& Matthew, O. (2017). Asuu begins indefinite strike. The Guardian Newspaper, https:/guardian.ng/news/asuu-begins-indefinite-strike/

Van den Tooren, M. \& de Jong, J. (2014). Job demands-resources and employee health and wellbeing: The moderating role of contract type. Career Development International, 19(1), 101122.

Yom, Y. H. (2010). The effects of organizational justice and dispositional affectivity on job satisfaction and intent to leave among nurses. Journal of Korean Academy of Nursing Administration, 16(3), 276-285. 